\title{
PENGARUH MODEL PEMBELAJARAN BERDASARKAN \\ MASALAH BERBANTU ANIMASI MACROMEDIA FLASH TERHADAP HASIL BELAJAR SISWA PADA MATERI LISTRIK DINAMIS
}

\author{
Darius J Padang dan Sehat Simatupang \\ Jurusan Fisika FMIPA Universitas Negeri Medan \\ Jalan Willem Iskandar Pasar V Medan \\ dariusjimmipadang@yahoo.com
}

\begin{abstract}
ABSTRAK
Penelitian ini bertujuan untuk mengetahui pengaruh model pembelajaran berdasarkan masalah berbantu animasi macromedia flash terhadap hasil belajar siswa pada materi listrik dinamis di kelas X SMA Negeri 1 Tanjung Morawa. Jenis penelitian ini adalah quasi eksperiment dengan populasi adalah seluruh siswa kelas X SMA Negeri 1 Tanjung Morawa yang terdiri dari 10 kelas.Pengambilan sampel dilakukan dengan cara cluster random samplingdengan mengambil 2 kelas yaitu kelas X-4 sebagai kelas eksperimen dan kelas X-3 sebagai kelas kontrol yang berjumlah 71 orang. Instrumen yang digunakan yaitu tes hasil belajar yang terdiri dari 20 soal pilihan berganda yang telah dinyatakan valid oleh validator.Dari data hasil penelitian diperoleh nilai rata-rata pretes kelas eksperimen adalah 39,43 dan nilai rata-rata kelas kontrol adalah 42,97. Setelah diberikan perlakuan yang berbeda, dimana kelas eksperimen menggunakan model pembelajaran berdasarkan masalah berbantu animasi macromedia flash dan kelas kontrol menggunakan pembelajaran konvensional, diperoleh nilai rata-rata postes kelas eksperimen 63,43 dan kelas kontrol 57,79. Dari hasil pengujian hipotesis diperoleh $t_{\text {hitung }}>t_{\text {tabel }}$, dimana $t_{\text {hitung }}=2,027>t_{\text {tabel }}$. Hasil penelitian menunjukkan, bahwa ada pengaruh akibat model pembelajaran berdasarkan masalah berbantu animasi macromedia flash terhadap hasil belajar siswa pada materi listrik dinamis di kelas X SMA Negeri 1 Tanjung Morawa T.A. 2013/2014.
\end{abstract}

Kata Kunci : Model Pembelajaran Berdasarkan Masalah, Hasil Belajar

\section{PENDAHULUAN}

Era globalisasi identik dengan pesatnya perkembangan Ilmu Pengetahuan dan Teknologi (IPTEK), yang akan mampu menghantarkan suatu bangsa pada era keterbukaan yang penuh dengan peluang dan tantangan. Salah satu faktor yang dibutuhkan untukmenghadapi era globalisasi tersebut adalah melalui proses pendidikan. Trianto (2010 : 1) mengatakan bahwa, pendidikan adalah salah satu bentuk perwujudan kebudayaan manusia yang dinamis dan sarat perkembangan. Oleh karena itu, perubahan atau perkembangan pendidikan adalah hal yang memang seharusnya terjadi sejalan dengan perubahan budaya kehidupan, dalam arti perbaikan 
pendidikan pada semua tingkat, harus terus menerus dilakukan sebagai antisipasi kepentingan masa depan. Pendidikan bertujuan untuk mengembangkan kemampuan potensi peserta didik.

Peserta didik sebagai generasi penerus bangsa perlu dibekali landasan karakter moral yang kuat, agar nilai-nilai jati diri sebagai suatu bangsa tidak luntur karena arus globalisasi. Keterampilan berpikir dalam memperoleh, mengolah, dan memaknai informasi dari berbagai sumber juga diperlukan untuk memecahkan suatu permasalahan dalam era globalisasi. Bekal tersebut, sebagian dapat diperoleh siswa di sekolah melalui pembelajaran fisika yang sesuai dengan hakikatnya sebagai sains. Sains adalah suatu kumpulan pengetahuan yang tersusun secara sistematik, dan penggunaanya secara umum tidak terbatas pada gejala-gejala alam. Perkembangan sains tidak hanya ditandai oleh adanya kumpulan fakta tetapi oleh adanya metode ilmiah dan sikap ilmiah. Sikap ilmiah ini yang diharapkan muncul pada diri peserta didik melalui pembelajaran di lembaga pendidikan, dengan tujuan untuk meningkatkan pengetahuan peserta didik, sehingga dibutuhkan pembelajaran yang berpusat pada peserta didik (student centered).

baru, $\begin{array}{rr}\text { Berdasarkan paradigma } \\ \text { pembelajaran }\end{array}$ dilaksanakan di lembaga pendidikan saat ini, harus berfokus pada pengembangan kemampuan intelektual yang berlangsung secara sosial dan kultural. Dalam konteks sosial, pembelajaran diharapkan mampu mendorong peserta didik mengembangkan pemahaman, serta pengetahuannya sendiri, dan dalam konteks kultural, pembelajaran dimulai dari pengetahuan awal dan perspektif budaya. Paradigma ini sesuai dengan pembelajaran yang dibutuhkan saat ini, yakni pembelajaran yang berpusat pada peserta didik (student centered). Oleh karena itu, untuk mencapai terciptanya pembelajaran yang berpusat pada peserta didik, maka guru harus mampu menciptakan suasana pembelajaran yang menarik dan berhubungan langsung dengan kehidupan sehari-hari.

$$
\text { Sanjawa (2011 : }
$$

mengatakan bahwa, salah satu masalah yang dihadapi dunia pendidikan saat ini adalah lemahnya proses pembelajaran. Kebanyakan proses pembelajaran yang dilakukan di lembaga pendidikan, peserta didik kurang didorong untuk mengembangkan kemampuan berpikir, melainkan peserta didik diarahkan kepada kemampuan untuk menghafal informasi; otak peserta didik dipaksa untuk mengingat dan menimbun informasi tanpa dituntut untuk memahami informasi yang dipelajarinya. Untuk itu, guru sebagai pemeran aktif dalam pelaksanaan proses pembelajaran diharapkan mampu mengubah pembelajaran yang berpusat pada guru (teacher centered), yakni; proses pembelajaran yang menyampaikan pengetahuanpengetahuan secara langsung kepada peserta didik, dengan pembelajaran yang mengembangkan kemampuan berpikir peseta didik, agar terwujud pembelajaran berpusat pada peserta didik (student centered). 
Hasil pengamatan penulis selama melakukan program praktik lapangan terpadu (PPLT) di SMA Swasta Teladan Pematangsiantar, peneliti memperoleh data, sebagian besar siswa mengatakan pelajaran fisika merupakan pelajaran yang sulit dipahami, membosankan, dan kurang menarik serta membuat siswa jenuh untuk belajar. Akibatnya adalah hasil belajar siswa terhadap pelajaran fisika rendah. Hal ini senada dengan hasil observasi peneliti di SMA Negeri 1 Tanjung Morawa, bahwa peneliti menemukan rendahnya hasil belajar siswa pada pelajaran fisika. Dari hasil wawancara dengan Dra. Julidar Pardede selaku guru mata pelajaran fisika di SMA Negeri 1 Tanjung Morawa, mengatkan hasil belajar siswa $65 \%$ masih dibawah kriteria ketuntasan minimal (KKM) yaitu 70 pada pelajaran fisika. Kemudian peneliti juga memberikan angket kepada siswa, untuk mengetahui bagaimana tanggapan siswa terhadap pelajaran fisika. Berdasarkan instrumen angket yang disebarkan kepada 30 siswa kelas X di SMA Negeri 1 Tanjung Morawa, diperoleh $66,67 \%$ (20 orang) siswa menganggap pelajaran fisika itu sulit dipahami dan kurang menarik, sedangkan untuk kegiatan belajar mengajar fisika di kelas, 83,33 \% (25 orang)siswa berpendapat kegiatan belajar mengajar fisika dikelas sulit dipahami dan membosankan. Disamping itu peneliti juga memperoleh data, bahwa guru kurang memvariasikan model pembelajaran, dan kurangnya pemanfaatan media saat proses pembelajaran. Rendahnya hasil belajar siswa pada pelajaran fisika merupakan gambaran, bagaimana tingkat kemampuan dan pemahaman siswa menguasai materi pelajaran masih rendah. Hal ini disebabkan proses pembelajaran masih lemah, pemilihan model pembelajaran kurang divariasikan untuk materi ajar tertentu. Oleh karena itu, guru harus mampu menciptakan suasana pembelajaran yang menarik, mudah, dan kreatif untuk meningkatkan aktivitas belajar peserta didik, yang bertujuan memperbaiki hasil belajar.

Dalam hal menciptakan suasana pembelajaran yang menarik, mudah, dan kreatif, dibutuhkan model pembelajaran yang sesuai terhadap materi ajar tertentu.Salah satu alternatif pemilihan model pembelajaran adalah pembelajaran berdasarkan masalah (problem based learning). Pelajaran fisika sangat erat hubungannya dengan model pembelajaran berdasarkan masalah. Hal ini dikarenakan pada model pembelajaran berdasarkan masalah yang disajikan, dapat memberikan kesempatan pada siswa untuk bereksplorasi, mengumpulkan dan menganalisis data untuk memecahkan masalah, sehingga pembelajaran menurut paradigma baru yaitu pembelajaran yang berpusat pada siswa (student centered) dapat terlaksana. Selain pemilihan model pembelajaran, hal yang juga perlu untuk menciptakan pembelajaran yang menarik adalah dengan memanfaatkan media pembelajaran.Media pembelajaran merupakan alat bantu unuk mempermudah penyampaian konsep terhadap materi tertentu. Oleh karena itu, peneliti ingin memanfaatkan media pembelajaran yaitu animasi macromedia flash. Hal inilah yang menjadi dasar 
pemilihan media ini, adalah karena sekolah SMA Negeri 1 Tanjung Morawa yang menjadi tempat penelitian telah memiliki sarana yang cukup untuk mendukung pemanfaatan animasi macromedia flash seperti; infokus dan instalasi sumber tegangan di ruangan kelas.

Bedasarkan uraian diatas, peneliti tertarik untuk melakukan penelitian dengan tujuan untuk mengetahui pengaruh model pembelajaran berdasarkan masalah berbantu animasi macromedia flash terhadap hasil belajar siswa pada materi listrik dinamisdi kelas $\mathrm{X}$ SMA Negeri 1 Tanjung Morawa.

\section{METODE PENELITIAN}

Penelitian ini dilaksanakan di SMA Negeri 1 Tanjung Morawapada semester genap Tahun Ajaran 2013/2014, dengan populasi adalah seluruh siswa kelas Xyang terdiri dari 10 kelas. Sampel diambil dengan teknik cluster random sampling, yakni kelas $\mathrm{X}-4$ sebagai kelas eksperimen dengan menggunakan model pembelajaran berdasarkan masalah berbantu animasi macromedia flash dan kelas X-3 sebagai kelas kontrol dengan menggunakan pembelajaran konvensional.

Adapun desain penelitian yang digunakan adalah desain pretest-posttest control group design, seperti yang ditunjukkan pada Tabel 1 .

Tabel 1.Two Group Pretest -

\begin{tabular}{|l|c|c|c|}
\hline \multicolumn{1}{|c|}{ Posttest Design } \\
\hline Kelas & Pretes & Perlakuan & Postes \\
\hline Eksperime & $\mathrm{X}_{1}$ & $\mathrm{~T}_{1}$ & $\mathrm{X}_{2}$ \\
\hline Kontrol & $\mathrm{X}_{1}$ & $\mathrm{~T}_{2}$ & $\mathrm{X}_{2}$ \\
\hline
\end{tabular}

(Sumber: Sugiyono, 2009)
Keterangan :

$$
\begin{aligned}
& \mathrm{T}_{1}=\text { Pembelajaran dengan } \\
& \text { menggunakan model } \\
& \text { pembelajaran berdasarkan } \\
& \text { masalah berbantu animasi } \\
& \text { macromedia flash }
\end{aligned}
$$

Alat pengumpulan data dalam penelitian ini adalah tes hasil belajar untuk mengetahui kemampuan kognitif siswa dengan menggunakan instrument tes soal pilihan berganda yang berjumlah 20 soal yang terlebih dahulu divalidasi oleh validator. Prosedur penelitian secara ringkas dijelaskan dalam Gambar 1.

\section{Uji Prasyarat (Pretes)}

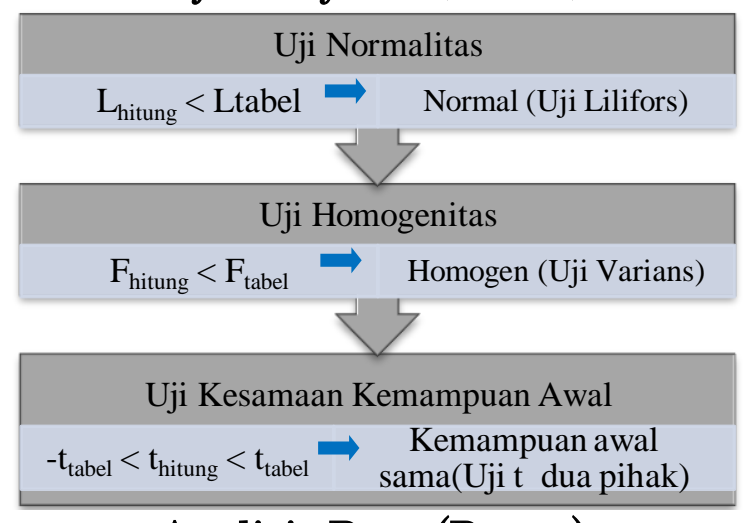

Analisis Data (Postes) 


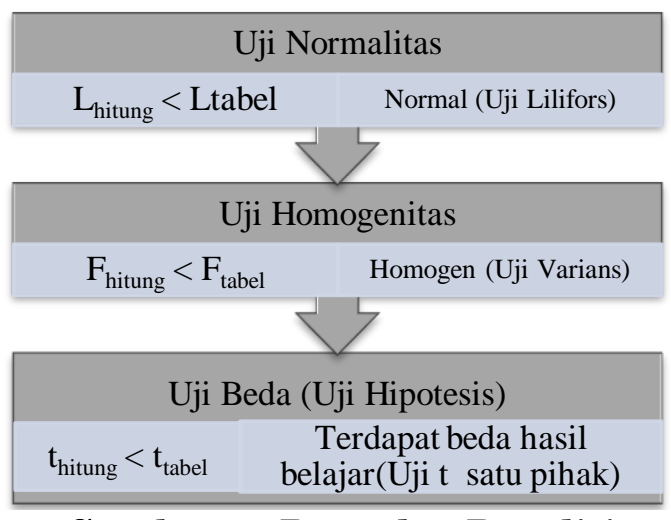

Gambar 1: Prosedur Penelitian

\section{HASIL PENELITIAN DAN PEMBAHASAN}

Penelitian ini termasuk penelitian quasi eksperiment. Data hasil penelitianuntuk pretesyang didapat pada kelas eksperimen dan kelas kontrol divisualisasikan pada Gambar 2.

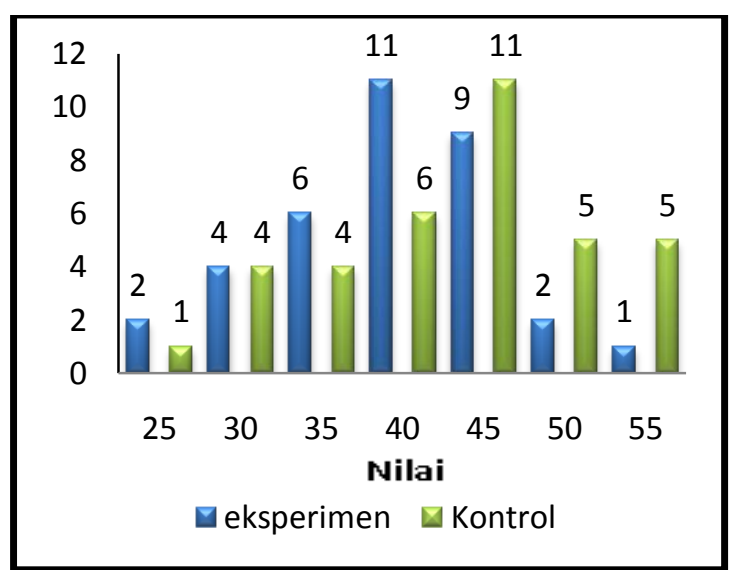

Gambar 2: Diagram batang nilai pre-test

Sebelum dilakukan perlakuan terhadap kedua kelas maka terlebih dahulu dilakukan analisis uji prasyarat Uji prasyarat dilakukan pada data pre-test. Uji prasyarat yang dilakukan antara lain uji normalitas, uji homogenitas, dan uji kesamaan kemampuan awal yang hasilnya ditunjukkan pada Gambar 3.

\begin{tabular}{|l|c|c|c|}
\hline \multicolumn{4}{|c|}{ Uji Normalitas } \\
\hline \multicolumn{1}{|c|}{ Kelas } & $\mathrm{L}_{\text {hitung }}$ & $\mathrm{L}_{\text {tabel }}$ & Kesimpuan \\
\hline Eksp. & $0,1262<0,1498$ & Normal \\
\hline Kontrol & \multicolumn{2}{|c|}{$0,1196<0,1476$} & Normal \\
\hline
\end{tabular}

\begin{tabular}{|l|c|c|c|}
\hline \multicolumn{4}{|c|}{ Uji Homogenitas } \\
\cline { 1 - 1 } \multicolumn{1}{|c|}{ Kelas } & $\mathrm{F}_{\text {hitung }}$ & $\mathrm{F}_{\text {tabel }}$ & Kesimpulan \\
\cline { 1 - 1 } Eksp. & \multicolumn{2}{|c|}{$1,38<1,86$} & Homogen \\
\cline { 1 - 1 } Kontrol & \multicolumn{2}{|c|}{} \\
\hline
\end{tabular}

\section{Uji Kesamaan Kemampuan Awal}

\begin{tabular}{|c|c|c|c|}
\hline Kelas & thitung & t tabel & Kesimpulan \\
\hline lks & \multirow{2}{*}{\multicolumn{2}{|c|}{$\begin{array}{l}-1,997<-1,921 \\
<1,997\end{array}$}} & \multirow{2}{*}{$\begin{array}{c}\text { Kemampuan } \\
\text { awal sama }\end{array}$} \\
\hline Kontrol & & & \\
\hline
\end{tabular}

Gambar 3. Uji Prasyarat

Berdasarkan hasil analisis data pretes, diperoleh bahwa data berdistribusi normal dan homogen.Data sampel berdistribusi normal dan homogen mengisyaratkan data memenuhi kriteria untuk uji-t (statistik parametrik).Kemudian dilakukan analisis data untuk mengetahui kesamaan kemampuan awal kedua kelas, hal ini perlu dilakukan untuk mengetahui bahwa sebelum dilakukan perlakuan yang berbeda sampel yang digunakan benar-benar memiliki kemampuan kognitif yang sama.

Setelah memenuhi persyaratan, selanjutnya diberikan pembelajaran dengan perlakuan yang berbeda terhadap kedua kelas untuk mengetahui kemampuan akhir dari perlakuan yang diberikan. Nilai rata-rata kognitif siswa setelah diberikan perlakuan melalui postesuntuk kelas eksperimen adalah 63,43 sedangkan untuk kelas kontrol adalah 57,79. 
Distibusi hasil belajar siswa untuk kelas eksperimen dan kelas kontrol divisualisasikan pada Gambar 4.

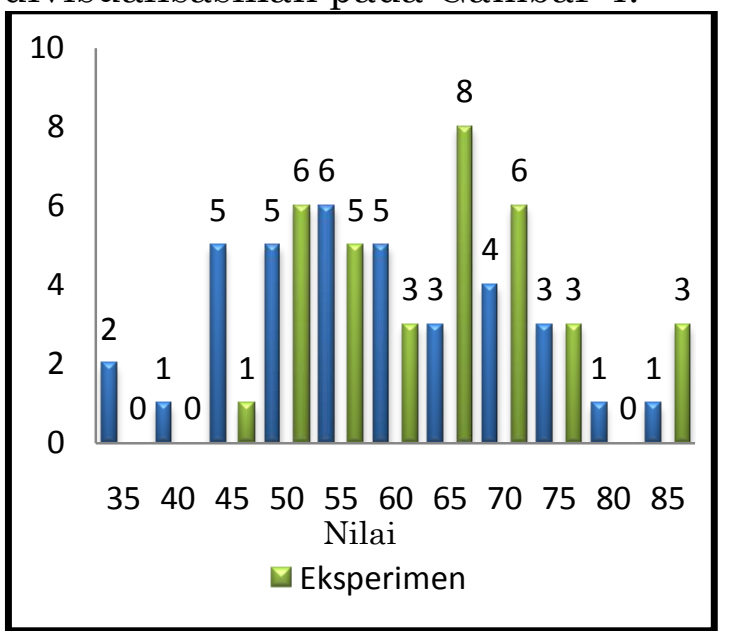

Gambar 4. Diagram batang nilai pre-test

Sebelum data dianalisis mengunakan uji beda (uji $t$ satu pihak) terlebih dahulu data tersebut di uji normalitas dan homogenitasnya, hal ini dilakukan untuk memenuhi persyaratan parametrik untuk selanjutnya dapat dilakukan uji t satu pihak untuk menjawab hipotesis penelitian. Analisis data secara ringkas ditunjukkan pada Gambar 5.

\begin{tabular}{|c|c|c|c|}
\hline \multicolumn{4}{|c|}{ Uji Normalitas } \\
\hline Kelas & $\mathrm{L}_{\text {hitung }}$ & $\mathrm{L}_{\text {tabe }}$ & Kesimpuan \\
\hline Eksp. & \multicolumn{2}{|c|}{$0,1311<0,1498$} & Normal \\
\hline Kontrol & \multicolumn{2}{|c|}{$0,1196<0,1476$} & Normal \\
\hline \multicolumn{4}{|c|}{ Uji Homogenitas } \\
\hline Kelas & $F_{\text {hitung }}$ & $\mathrm{F}_{\text {tabel }}$ & Kesimpulan \\
\hline $\begin{array}{l}\text { Eksp. } \\
\text { Kontrol }\end{array}$ & \multicolumn{2}{|c|}{$1,35<1,86$} & Homogen \\
\hline \multicolumn{4}{|c|}{ Uji Beda (Uji Hipotesis) } \\
\hline Kelas & thitung & $t_{\text {tabel }}$ & Kesimpulan \\
\hline $\begin{array}{l}\text { Eksp. } \\
\text { Kontrol }\end{array}$ & \multicolumn{2}{|c|}{$2,028>1,668$} & $\begin{array}{l}\text { Ada perbedaan } \\
\text { hasil belajar }\end{array}$ \\
\hline
\end{tabular}

Gambar 5: Analisis data penelitian
Kriteria pengujian $t_{\text {hitung }}>t_{\text {tabel }}$ (2,028> 1,668), hipotesis penelitianditerima bahwa hasil belajar siswa akibat pengaruh model pembelajaran berdasarkan masalah lebih baik dibandingkan dengan pembelajaran konvensional, dapat dinyatakan bahwa ada pengaruh akibatmodel pembelajaran

berdasarkan masalah menggunakan animasi macromedia flash terhadap hasil belajar siswa pada materi listrik dinamis di kelas $\mathrm{X}$ semester II SMA Negeri 1 Tanjung Morawa T.A. 2013/2014.

Hasil penelitian menunjukkan, bahwa hasil belajar siswa dengan menggunakan model pembelajaran berdasarkan masalah berbantu animasi macromedia flash, lebih baik dibandingkan dengan hasil belajar siswa menggunakan pembelajaran konvensional,hal ini dapat dilihat dari hasil postes kelas eksperimen memperoleh rata-rata nilai 63,43 , sedangkan hasil postes di kelas kontrol memperoleh ratarata nilai 57,79 .

Model pembelajaran berdasarkan masalah lebih baik dari pada pembelajaran konvensional, karena memberikan peluang kepada siswa secara aktif terlibat dalam kegiatan pembelajarannya,hal ini terlihat melalui fase demi fase dalam model ini khususnya fase ketiga, dimana siswa melakukan investigasi atau penyelidikan secara berkelompok dengan bereksperimen langsung untuk memecahkan masalah terkait materi yang dibahas yakni listrik dinamis. Melalui eksperimen siswa dituntut untuk dapat memberdayakan kemampuan berpikir sesuai pengetahuan yang dimiliki, dalam hal mengemukakan hipotesis 
percobaan dan menganalisis hasil percobaan, serta menarik kesimpulan, sehingga apa yang diperoleh oleh siswa tidak hanya mengingat fakta-fakta melainkan menemukan langsung fakta. Keterlibatan siswa secara aktif dalam kegiatan pembelajaran berdasarkan masalah juga terlihat melalui fase keempat, dimana siswa secara berkelompok ditugaskan untuk mengembangkan hasil eksperimen dalam bentuk laporan diskusi,dengan diskusi siswa akan berusaha menemukan dan mempelajari konsep-konsep materi pelajaran serta berusaha untuk memunculkan ide-ide yang dimiliki dalam hal pemecahan masalah yang dibahas, dengan kegiatan ini maka siswa tidak hanya sekedar mengingat materi pelajaran yang dibahas, akan tetapi siswa mampu menguasai dan memahaminya secara penuh. Dalam fase ini juga siswa secara berkelompok ditugaskan untuk mempresentasikan kepada teman dan guru hasil laporan diskusi yang dikerjakan, sehingga dengan kegiatan ini siswa akan memperoleh kemampuan berkomunikasi dalam presentasi, menanggapi pendapat orang lain, bertanggung jawab dan berpikir logis yang merupakan cerminan dari sikap, hal ini terlihat dari hasil observasi sikap siswa selama kegiatan pembelajaran mengalami peningkatan tiap pertemuan. Melalui fase tersebut juga, keterampilan siswa akan muncul, misalanya keterampilan dalam melakukan percobaan, menggunakan alat praktikum, dan mengumpulkan data percobaan, serta membuat laporan hasil diskusi, hal ini dapat dilihat dari hasil observasi keterampilan siswa selama pembelajaran berlangsung, nilai keterampilan siswa meningkat tiap pertemuan.

Pembelajaran berdasarkan

masalah berbantu animasi

macromedia flashdapat juga meningkatkan aktivitas belajar siswa, hal ini ditunjukkan dari hasil observasi aktivitas belajar siswa, mulai pertemuan I.Pada pertemuan ini aktivitas belajar siswa tergolong masih kurang aktif. Tetapi seiring dengan berlangsungnya pembelajaran yang melibatkan siswa dalam kegiatan pembelajarannya, dimana siswa melakukan eksperimen, membuat laporan hasil diskusi, mengajukan pertanyaan dan memberikan pendapat untuk pemecahan masalah, sehingga siswa termotivasi untuk belajar aktif hingga pertemuan III, aktivitas belajar siswa menjadi meningkat dengan kategori aktif. Keterlibatan siswa secara aktif dalam pembelajaran akan dapat meningkatkan hasil belajar siswa dan sikap siswa lebih baik tehadap suatu pelajaran. Hasil belajar siswa di kelas eksperimen lebih baik adalah akibat pengaruh pengguanaan model pembelajaran berdasrkan masalah berbantu animasi macromedia flash.

Namun demikian, masih terdapat kendala pada saat menerapkan model pembelajaran berdasarkan masalah dalam penelitian ini yang menyebabkan pencapaian hasil belajar kurang maksimal.Kendala-kendala tersebut adalah seperti; 1) perencanaan kegiatan belajar mengajar dalam RPP tidak sesuai dengan kenyataan, karena kurangnya waktu.Hal ini terlihat pada fase ketiga saat pelakasanaan praktikum siswa terlalu ribut, karena siswa kurang 
mampu dalam melakukan praktikum sesuai prosedur. Siswa lebih banyak bertanya kepada guru tentang cara melakukan praktikum, khususnya cara penggunaan alat ukur yaitu multimeter. Apabila saat melakukan praktikum siswa mengerjakan sesuai prosesur kerja, maka kondisi kelas tidak akan ribut dan penggunaan waktu yang direncanakan dalam RPP akan sesuai. Jika ingin menggunakan model pembelajaran berdasarkan masalah, guru terlebih dahulu menjelaskan prosedur kerja dan cara penggunaan alat praktikummelalui demostrasi sebelum praktikum dimulai sekitar lima menit, sehingga apa yang direncanakan dalam kegiatan belajar mengajar dalam RPP sesuai. 2) pada saat menyajikan hasil diskusi, sebagian siswa kurang antusias untuk presentasi melainkan memilih diam dan menunggu pendapat temannya, hal ini dikarenakan siswa masih pertama kali menerima pembelajaran berdasarkan masalah sehingga kurang memahami kegiatan pembelajaran yang berlangsung dan kemampuan siswa pada kelas eksperimen masih tergolong rendah, yaitu memperoleh rata-rata pretes 39,43 , sehingga kurang mendukung terlaksananya pembelajaran ini. Pembelajaran berdasarkan masalah dapat berlangsung dengan baik jika siswa berani mengungkapkan pendapat, serta memiliki tingkat analisis berpikir tinggi. Apabila siswa lebih berani mengeluarkan pendapat untuk memecahan masalah dalam diskusi, makaakan banyak informasi yang didapat, dan pembelajaran yang melibatkan siswa aktif akan tercapai melalui model ini. Jika ingin menggunakan model pembelajaran berdasarkan masalah lebih baik menerapkannya pada kelompok siswa yang memiliki kemampuan berpikir cukup tinggi.3) kurangnya pengalaman peneliti dalam mengelola kelas sehingga kondisi kelas kurang kondusif menyebabkan penelitian menjadi kurang efisien, karena penelitipun masih belajar menjadi seorang guru yang profesional, dan penelitipun hanya dibantu oleh dua orang observer.Jika ingin melakukan penelitian menggunakan model pembelajaran berdasarkan masalah, seorang peneliti harus menambah jumlah observer dari jurusan yang sama dengan peneliti untuk membantu peneliti saat siswa melakukan eksperimen serta mengkoordinir kondisi kelas sehingga kondusif.

\section{KESIMPULAN DAN SARAN \\ Kesimpulan}

Berdasarkan hasil analisis data penelitian dapat disimpulkan bahwa ada pengaruh akibat model pembelajaran berdasarkan masalah menggunakan animasi macromedia flash terhadap hasil belajar siswa pada materi listrik dinamis di kelas X semester II SMA Negeri 1 Tanjung Morawa T.A. 2013/2014.Pengaruh tersebut menunjukkan hasil belajar siswa pada kelas eksperimen lebih baik dibandingkan hasil belajar siswa pada kelas kontrol.Model pembelajaran berdasarkan masalah juga dapat meningkatkan aktivitas belajar siswa. 


\section{Saran}

Berdasarkan hasil dan kesimpulan dalam penelitian ini, maka peneliti mempunyai beberapa saran :

1. Bagi mahasiswa calon guru atau guru yang ingin menerapkan model pembelajaran berdasarkan masalah, sebaikknya memperhatikan efisiensi waktu untuk tiap fase dalam model ini, khususnya pada fase ketiga saat melakukan investigasi melalui eksperimen Ada baiknya terlebih dahulu menjelaskan kepada siswa prosedur praktikun yang akan dikerjakan, khusunya cara penggunaan alat praktikum di luar kegiatan pembelajaran yang akan berlangsung. Sehingga waktu dalam kegiatan pembelajaran melalui model ini akan lebih ekfektif dan efisien.

2. Bagi mahasiswa calon guru yang ingin melakukan penelitian yang sama, sebaiknya memilih kelompok siswa yang mempunyai kemampuan rata-rata berpikir cukup tinggi. Pelaksanaan model pembelajaran berdasarkan masalahakan lebih baik jika siswa dalam pembelajaran aktif dan berani mengeluarkan pendapat untuk pemecahan masalah.

3. Bagi mahasiswa calon guru yang ingin melakuan penelitian menggunakan model pembelajaran berdasarkan masalah, seorang peneliti harus menggunakan observer minimal tiga orang dari jurusan yang sama dengan peneliti, untuk membantu peneliti saat siswa melakukan eksperimen serta mengkoordinir kondisi kelas sehingga kondusif.

\section{DAFTAR PUSTAKA}

Arends, R. I., (2008), Learning to Teach (Belajar untuk Mengajar), Penerbit Pustaka Pelajar, Yogyakarta.

Arikunto, S., (2011), Dasar-Dasar Evaluasi Pendidikan, Penerbit Bumi Aksara, Jakarta.

Arsyad, A., (2007), Media Pembelajaran, Penerbit PT Raja Grafino Persada, Jakarta.

Eggen, P. \& Kauchak, D., 2012, Strategi dan Model Pembelajaran, Indeks, Jakarta Barat

Hamalik, O., (2010), Proses Belajar Mengajar, Penerbit Bumi Aksara, Jakarta.

Lindley, D.V., \& Scott, W.F., 1995, New Cambridge Statistical Tables Second Edition, Cambridge University Press, Massachusetts

Newman, Mark J., (2005), Problem Based Learning: An Inroduction and Overview of the key Features of the Approach, Journal of Veterinary 12: L:/Inprocess/UTPress/JVME/J VME32(1)-Revises-2/JVME003.3d

Pohan, A.H., (2012), Pengaruh Model Pembelajaran Berdasarkan Masalah Terhadap Hasil Belajar Siswa Pada Materi Pokok Listrik Dinamis Kelas IX SMP N 5 Pematangsiantar T.P 2012/2013, FMIPA Unimed, Medan.

Rusman, (2012), Model-Model Pembelajaran Mengembangkan Profesionalisme

Guru, 
Penerbit Raja Grafindo

Persada, Jakarta.

Sanjaya, H.W., (2011), Strategi Pembelajaran Berorientasi Standar Proses Pendidikan, Kencana Prenada Media, Jakarta

Sitanggang, N., (2012), Pengaruh Model Pembelajaran Berbasis Masalah Terhadap Hasil Belajar Siswa Pada Maeri Kesetimbangan Benda Tegar

$$
\text { Kelas XI MAN } 1 \text { Medan }
$$

T.P 2011/2012, FMIPA

Unimed, Medan.

Slameto, (2010), Belajar Dan Faktor-Faktor Yang Mempengaruhinya, Penerbit Rineka Cipta, Jakarta.

Sudjana, (2005), Metode Statistika, Penerbit Tarsito, Bandung.

Sudjana, N., (2009), Penilaian Hasil Proses Belajar Mengajar, Penerbit PT. Remaja Rosdakarya, Bandung.

Sugiyono, (2009), Metode Penelitian Pendidikan Pendekatam Kalitatif, Kuantitatif, Dan $R \& D, \quad$ Penerbit Alfabeta, Bandung.

Yolanda, R., (2011), Pengaruh Pembelajaran Problem Based Learning Terhadap Hasil Belajar Fisika Siswa Kelas $X$ SMA Negeri 1 Labuhan Deli Pada Materi Gerak Lurus Beraturan T.P 2010/2011, FMIPA Unimed, Medan.

Sukinto, M.S., (2013), Belajar Dan Pembelajran, Penerbit Holistika Lombok, Lombok.

Trianto, (2009), Mendesain Model Pembelajaran InovatifProgresif, Konsep Landasan dan Implementasinya, Penerbit Kencana, Jakarta. 